\title{
A Compact-Cell Sensor based on Diazacrown Ether Derivative for the Determination of Ephedrine
}

\author{
Ali A. Keshk, ${ }^{1, *}$, Meshari A. Alsharifl, and Mohsen M. Zareh ${ }^{2}$ \\ ${ }^{1}$ Department of Chemistry, Faculty of Science, University of Tabuk, Tabuk, Saudi Arabia. \\ ${ }^{2}$ Department of Chemistry, Faculty of Science, Zagazig University, 44519 Zagazig, Egypt. \\ *E-mail: akeshk@ut.edu.sa,mohsenzareh2@gmail.com, mmzareh@zu.edu.eg
}

doi: $10.20964 / 2019.08 .73$

Received: 13 February 2019 / Accepted: 13 May 2019 / Published: 30 June 2019

In this study, a compact-cell sensor based on a plastic-membrane was introduced for the determination of ephedrine (EP) in pharmaceutical formulations. The sensing membrane of the sensor cell was made of either potassium tetrafluorophenyl borate (type-I) or $\mathrm{N}$, N-bis-ethoxycarbony-1,4,7,10,13,16hexaoxacyclooctadecane (type-II). The developed sensor exhibited typical Nernstian response (59.8 $\mathrm{mV} / \mathrm{decade}$ ) and high sensitivity (pM 6.2). The sensor was found to work in a $\mathrm{pH}$ range of 3.1-8.96 and showed good selectivity for EP relative to other organic and inorganic interferent. The sensor was applied effectively for the assessment of EP in different pharmaceutical formulations.

Keywords: Ephedrine, compact cell sensor, PVC membrane electrode.

\section{FULL TEXT}

(C) 2019 The Authors. Published by ESG (www.electrochemsci.org). This article is an open access article distributed under the terms and conditions of the Creative Commons Attribution license (http://creativecommons.org/licenses/by/4.0/). 